\title{
LOVE OF COMRADES: THE URBANIZATION OF COMMUNITY IN WALT WHITMAN'S POETRY AND PRAGMATIST PHILOSOPHY
}

\author{
Frances Dickey and M. Jimmie Killingsworth
}

AT THE INTERSECTION of pragmatism and urbanization in American culture stands Walt Whitman. Long recognized as "America's first urban poet," Whitman also has an important relation to pragmatist thought. From William James, who quotes at length from "Crossing Brooklyn Ferry" in "On a Certain Blindness in Human Beings," to Richard Rorty, who likens Dewey's liberalism to Whitman's in Achieving Our Country, philosophers and critics have worked to articulate what that relation is. ${ }^{2}$ Rather than following the recent trend of viewing Whitman as a pragmatist avant la lettre, we argue that the social crisis produced by urbanization shaped Whitman's poetry and pragmatist thought in similar ways.

As the participial title of "Crossing Brooklyn Ferry" suggests, Whitman was really an urbanizing, rather than urban, poet. His experience of the city in his middle life, the experience that prompted his best poems, was mediated by his earlier experience in the country. Like many men of his generation, he moved from village to city. His poems bear the signs of a mind adjusting to a new sense of identity and community. The first two editions of Leaves of Grass (1855 and 1856) begin with a tone of great hope and eager celebration that grows conflicted in subsequent editions, notably 1860 and 1867 , in which we find the poet arriving at a new understanding of communal relationships in modern urban environments. In working through this process, Whitman experienced a skepticism to which the pragmatists would also respond. Focusing on poems that arose during the crisis period in the late 1850 s, we argue that the older poet-straddling the generation of the elder Henry James and that of his son William-captures poetically the kinds of conflicts within an urbanizing culture that also influenced the formation of pragmatist theories of community: Peirce's community of inquiry, Royce's Christian community, and Dewey's democracy.

\section{Skepticism and Community}

The long history of urbanization in Europe and America is also the history, in philosophy, of the articulation of skepticism about whether 
and how we know other people. The characteristically urban experience of coming face to face with a person you've never seen before and may never see again raises doubts about the assumptions commonly brought to social interactions. Does this person feel as I do? What is he thinking about me? Do we share any beliefs in common? Do his words and gestures mean the same to him as they seem to mean to me? Long before the advent of the "great" city, but at the cusp of the modern period, Descartes articulated the problem of other minds-do other people have minds, and how do I know this? - in the context of seeing a stranger on the street. During the Second Meditation, debating whether knowledge of things derives from the senses or the intellect, Descartes looks out the window and sees men crossing the square. "Yet do I see any more than hats and coats which could conceal automatons? I judge that they are men. And so something which I thought I was seeing with my eyes is in fact grasped solely by the faculty of judgement which is in my mind." Seeing men he does not know socially, he realizes that his confidence in their likeness to him is based on a process of reasoning, not on sensory evidence. Though Descartes himself does not question this reasoning, a long series of philosophers after him elaborate on the problem and acknowledge that much of our confidence in the existence of other minds is unfounded. It is profoundly a modern problem, testified to by the way Descartes, and after him John Stuart Mill, situate it in the context of seeing men walking in city streets.

In poetry, this peculiarly urban skepticism finds its inaugural expression in Baudelaire's "A une passante" from the 1848 Fleurs du Mal. In this sonnet, beginning with the words "La rue," the speaker conceives a passion for a woman in mourning he sees picking her way through the deafening street traffic. Shaking from the shock of the meeting, he mourns that he will not see her again:

Car j'ignore où tu fuis, tu ne sais où je vais,

Ô toi que j'eusse aimée, ô toi qui le savais!

[Neither do I know where you go, nor you know where I go, O you I might have loved, o you who know it well!! ${ }^{4}$

These lines crown a series of unbearable oppositions (the woman's sexual availability and her remoteness, his rush of passion and depression of loss, the "pleasure that kills"), expressing both the sense of not knowing the woman (anything about her life, her self), and an intuition of shared feeling. This intuition of commonality, however, cannot be proven, and thence stems his anguish. Indeed, the closing lines inspire skepticism in $u s$, as we ask, "how does he know that she knows? He might well be wrong." This conflict between, on the one hand, the desire for and confidence in intimacy, and on the other, the stunning lack of evidence for any such mutual understanding is central to the experience of urban 
encounters as this poem presents them, and indeed as Whitman also represents them in his turn.

The pragmatists, by contrast, do not concern themselves so much with skepticism about other minds; rather, they find ways to circumvent this disabling and insoluble problem. William James's famous 1892 lecture, "On a Certain Blindness in Human Beings," begins by posing a version of the problem of other minds, only to show his listeners that it's a false problem. Significantly, this essay instantiates the historical connection between Whitman and pragmatism, recruiting the poet to show his fundamental confidence in the universality of human experience.

The "certain blindness in human beings" that furnishes James's title is his name for the problem we have in knowing one another's minds. When we think we understand other people's experiences, he warns, we run the danger of dismissing those experiences as far more mundane or meaningless than they are. His lesson

forbids us to be forward in pronouncing on the meaninglessness of forms of existence other than our own; and it commands us to tolerate, respect, and indulge those whom we see harmlessly interested and happy in their own ways, however unintelligible these may be to us. Hands off: neither the whole of truth nor the whole of good is revealed to any single observer, although each observer gains a partial superiority of insight from the peculiar position in which he stands. (James 169)

This final paragraph of the lecture seems to suggest not only that our subjective "blindness" towards others is an intrinsic feature of human knowing, preventing one person from seeing the world the way another does, but further, that our imprisonment in our individual perspectives prevents anyone from ever grasping "the whole of truth." James's conclusion combines two distinguishable views: a skepticism about one's capacity to know how other people feel and think, followed by a kind of perspectivism that generalizes the individual's (epistemological) problem of knowing others to the (metaphysical) view that "the whole of truth" itself is beyond human understanding, and perhaps may not exist as such. Each perspective, instead, constitutes a world that may have little in common with its neighbor.

James's combination of skepticism and relativistism, as he appears to articulate it at the beginning and ending of his lecture, leads Alan Trachtenberg in a recent essay to describe pragmatism as the view that "truth is plural and partial, subjective, fragmented, scattered." Importantly for our purposes, Trachtenberg identifies Whitman's "processional" method in "Crossing Brooklyn Ferry" and other city poems with this version of pragmatism. Trachtenberg implies that Whitman's special and original sensitivity to the conditions of urban life enabled him to intuit this "plural," "subjective" view of truth that James would later articulate philosophically. Indeed, a version of perspectivism is the one most commonly associated with pragmatism (itself a bewilderingly het- 
erogeneous collection of arguments), articulated and popularized by Richard Rorty, Whitman's most recent claimant.

Yet this view is actually not the one James takes throughout his essay, nor is it Whitman's view in "Crossing Brooklyn Ferry," from which James quotes thirty lines. In "A Certain Blindness" James primarily oscillates between skepticism about whether we can know what other people think and feel, and a thorough confidence in the power of communication - testimony-to describe the states of mind experienced by particular individuals whom he quotes. The exemplary instance of this oscillation is James's own anecdote at the beginning of the essay about an experience he had while traveling in the wilds of North Carolina:

I passed by a large number of 'coves,' as they call them there, or heads of small valleys between the hills, which had been newly cleared and planted. The impression on my mind was one of unmitigated squalor. . . . The forest had been destroyed; and what had 'improved' it out of existence was hideous, a sort of ulcer, without a single element of artificial grace to make up for the loss of Nature's beauty. (James 151)

Horrified by the raw ugliness of this rural life (devoid of the "beauties and commodities" of culture), he turns to his mountaineer guide to ask, "What sort of people are they who have to make these new clearings?" The guide's answer catalyzes James's revelation about other minds: “All of us,' he replied. 'Why, we ain't happy here, unless we are getting one of these coves under cultivation." James realizes instantaneously that what looks to him like a squalid scene "was to them a symbol redolent with moral memories and sang a very paean of duty, struggle, and success." Thus, the very moment at which he fully confronts the opacity and remoteness of the Carolinians' minds is also the moment in which he finds out what they think. Though he points out that he was previously blind to their point of view, the real lesson of the story lies in his satisfying interaction with his guide, whose testimony inspires in him an imaginative recreation of the Carolinian mind. James, here, is neither skeptical nor a perspectivist: he believes in the capacity of shared and compared testimony to compensate for our individual limitations of position.

So, despite the title of his lecture, James's real subject is not our blindness to others' minds and emotions, but precisely our capacity to respond to their testimony with sympathetic insight. What James exhorts is our willingness to respond. The form of the lecture reproduces the model of testimony that he suggests in his opening anecdote: it consists almost entirely of a series of quotations from poetic, fictional, and autobiographical texts describing moments of private revelation. Each passage (by authors including R. L. Stevenson, Josiah Royce, Emerson, Wordsworth, Benvenuto Cellini, Tolstoy, W. H. Hudson, as well as Whitman) presents an experience that outwardly seemed either ordi- 
nary or unpleasant (Emerson crossing Boston Common, Wordsworth looking at a landscape, Peter's experience as a prisoner of war in War and Peace, Cellini's solitary confinement) and yet inwardly transformed the speaker's world and infused it with meaning. These passages not only support James's thesis that one person's boring walk to work can be another's epiphany; they testify to a particular kind of rapture that might seem to be utterly private and yet turns out to be shared in common among all the speakers. The aggregate of their remarks constitutes a kind of community of inquiry or ratification.

The concept of community as a way of finding out about the world originates with the first pragmatist writings of Charles Sanders Peirce. In "How to Make Our Ideas Clear," Peirce applied the system of peer review in the sciences to his theory of truth, which he argued represented the outcome of inquiry carried out by a community of investigators for an indefinitely long time: "The opinion which is fated to be ultimately agreed to by all who investigate, is what we mean by the truth, and the object represented in this opinion is the real." 6 This essay elaborates on a remark of ten years before, that

the real, then, is that which, sooner or later, information and reasoning would finally result in, and which is therefore independent of the vagaries of me and you. . . . [T] he very origin of the conception of reality shows that this conception essentially involves the notion of a COMMUNITY. ${ }^{7}$

This is the "community of inquiry." James's colleague Josiah Royce, a Hegelian, was deeply influenced by Peirce's conception of truth as evolving over time through the interaction of a community. Peirce's influence is particularly reflected in later works such as The Problem of Christianity, in which Royce argues that not only knowledge but the world itself is a continuous creation by members of the community, who listen to, interpret, and explain each other's points of view. ${ }^{8}$ Peirce's theory of the community of inquiry, as well as versions developed by Royce, James, and Dewey, relies particularly on the assumption that our experiences can be intelligibly communicated and usefully compared.

This similarity of experience from person to person is one of the subjects of Royce's earlier and more famous work, The Religious Aspects of Philosophy (1885), from which James quotes in "On a Certain Blindness." He cites Royce not to substantiate his opening claim that we don't know what other people are thinking, but rather, his real claim that we can be pretty sure we do know:

Pain is pain, joy is joy, everywhere, even as in thee . . everywhere, from the lowest to the noblest, the same conscious, burning, wilful life is found, endlessly manifold as the forms of the living creatures, unquenchable as the fires of the sun, real as these impulses that even now throb in thine own little selfish heart. (James 156) ${ }^{9}$ 
According to this view, truth is not "plural" in the sense that everybody's experience is inaccessibly different and other, but rather, truth is discovered through comparing testimony from multiple points of view. (In a sense, it is just evidence that is plural.) If our points of view contradict rather than confirm each other, then we return to our experiments (experiences) to test the world again; we don't need to fall back to skepticism about other minds. Though Royce and James emphasize the moment of convergence (we all experience rapture at odd moments), the community of inquiry needs both convergence and contradiction in order to work. Encounter with unfamiliar others need not lead to doubt about their minds and natures: it can lead to a better understanding of the world. That, anyway, is what happens to James in the anecdote he tells about himself.

The relationship between skepticism and community is central to Whitman's developing urban sensibility, as well as to pragmatist thought. Skepticism about other minds and the community of inquiry are not really compatible: if individuals doubt whether they can ever know what others' thoughts or feelings are like, then the others' testimony won't help that doubt. Yet, both skepticism about other minds and a practice of the community of inquiry might conceivably arise from the same experience of urbanization, variously understood either as the alienating encounter with strangers, or the stimulating opportunity to check other people's testimony. In fact, Whitman experiences both responses to urbanization.

Significantly, James's exemplary anecdote precisely addresses the cultural gap between rural and urban sensibility that is our subject. $\mathrm{He}$ sums up: "I had been as blind to the peculiar ideality of their conditions as they certainly would also have been to the ideality of mine, had they had a peep at my strange indoor academic ways of life at Cambridge." The problem of other minds that James treats in "On a Certain Blindness" is fundamentally a problem of the difference between those who live in the country and those who live in the city. James, however, unlike Whitman, reveals himself here as an inveterate city-dweller, unable to inhabit the perspective of the rural settler. James, whose skepticism does not run deep at all, represents a later generation for whom urban life is the norm (though note the "indoor academic ways of life" that shield him from the anonymity of the street crowd), rather than the smalltown existence that Whitman knew. The problem, however, is in many respects the same: skepticism about other minds arises during the encounter with strangers whose experiences are significantly different from ours. For Whitman, as for his contemporary Charles Baudelaire (and $T$. S. Eliot later), the encounter with strangers takes place in the street of the industrializing city.

As James reveals in his essay, and as many twentieth-century philosophers have concluded, skepticism about other minds is more easily 
dismissed than it is solved by recourse to evidence. In order to present evidence about what other people experience, James must already believe that their testimony accurately reflects their thoughts (a step the skeptic will not take). Thus, the community of inquiry is not a solution to skepticism so much as a way around it, a route to greater confidence. The story of Whitman's urbanization (as it were) is not the story of his confidence about what others think, so much as a story of his discovery of skepticism and his search for strategies that can take him beyond that disabling doubt.

\section{Early Urbanizing in Whitman}

The first poems published in Leaves of Grass embrace a universalizing rhetoric that cuts through the problem of urban alienation by energetically denying it. In the famous opening poem of 1855 (later titled "Song of Myself"), Whitman proclaims, "I celebrate myself," to which he adds an imposition on the reader- "And what I assume you shall assume"-then completes the flourish with a negation of the difference between "me" and "you": "For every atom belonging to me as good belongs to you" (27). ${ }^{10}$ The poet's unabashed use of the first person and even his own nickname- "Walt Whitman, an American, one of the roughs, a kosmos" (50)—struck many readers as outrageous in his own day, but from a modernist perspective, his self-absorption is less outrageous than his assumption of what he called sympathy, the ability through which he claimed to know the minds and hearts of others: "whatever is done or said returns at last to me" (50). For the inspired poet, the sympathetic imagination knows no bounds, neither gender ("My voice is the wife's voice, the screech by the rail of the stairs" [64]), nor race ("I am the hounded slave ... . I wince at the bite of the dogs" [65]), nor the extreme ranges of experience, such as crime ("Not a youngster is taken for larceny, but I go up too and am tried and sentenced" [70]), great adventure and even death ("I am the mashed fireman with breastbone broken" [65]). The distance that the poet claims to overcome through sympathy is comparable to the distance that strangers feel from one another in the great city and also the distance between the poet and the mass audience in the age of print-another gap across which the poet reaches, addressing his readers as lovers in the second untitled poem of 1855 (later "A Song of Occupations"):

Come closer to me,

Push close my lovers and take the best I possess,

Yield closer and closer and give me the best you possess.

This is unfinished business with me . . . how is it with you?

I was chilled with the cold types and cylinder and wet paper between us. (89) 
The untamed flow of sympathy culminates in "Crossing Brooklyn Ferry," a poem that dates from the second (1856) edition of Leaves of Grass. In this, his finest celebration of urban life, the poet muses upon the pressing crowds and the traffic on the great fast-flowing river that separates Manhattan from Brooklyn. "Thrive cities," he sings out in his closing section, "bring your freight, bring your shows, ample and sufficient rivers" (313). The city and its environment flow together in Whitman's imagination, recalling a metaphor he applied to Broadway in a feature article from the same period: "that ever-flowing land-river, pouring down through the center of Manhattan Island." ${ }^{11}$ On the ferry, one of the city's earliest forms of mass transportation-"a striking instance of how, in a democracy, what used to be a privilege of the few was now being made available to all"12 - the poet enjoys a magnetic connection with the throngs of people he meets: "What gods can exceed these that clasp me by the hand, and with voices I love call me promptly and loudly by my nighest name as I approach" (312). And now the human kinship the poet feels among his fellow citizens extends to the future, the distance of both the print medium and time itself yielding before the sympathetic imagination:

It avails not, time nor place-distance avails not,

I am with you, you men and women of a generation, or ever so many generations hence,

Just as you feel when you look on the river and sky, so I felt,

Just as any of you is one of a living crowd, I was one of a crowd,

Just as you are refresh'd by the gladness of the river and the bright flow, I was refresh'd,

Just as you stand and lean on the rail, yet hurry with the swift current, I stood yet was hurried,

Just as you look on the numberless masts of ships and the thick-stemm'd pipes of steamboats, I look'd. (308-309)

Whatever readers in his own time may have thought about the poet's faith in his oneness with others, readers in the twenty-first century are likely to look with cynical irony or with a deep sense of loss upon the poet's faith that his experiences would align with those of future readers. Whitman could not have imagined the isolation that comes with automobile travel - each individual enclosed within his own bubble of glass and steel, protected from contact with other people and from the choking atmosphere of exhaust, careening across the river on asphalt high above the water. It would take an act of denial on the Whitmanian scale for the modern reader not to feel the tug of resistance when the poet asserts, after a long catalog of waterfront images, "These and all else were to me the same as they are to you" (310).

Whitman's insistent universalizing has roots in Romanticism and may owe a particular debt to Emerson, whose concept of "self-reliance" 
included the dictum: "To believe your own thoughts, to believe that what is true for you in your private heart is true for all men,- - that is genius. Speak your latent conviction, and it shall be universal sense."13 But Whitman added a communal element that bespoke his experiences among classes of people and kinds of places that would have been utterly foreign to a person like Emerson. Historical scholarship has convincingly identified Whitman's outlook in the early Leaves with the artisanal republican culture of his father's time, a culture of craftsmen rooted in local life and marked by an almost fanatical devotion to comrades and an equally fervent suspicion of the centralizing forces of government and corporate industry. In The Lunar Light of Whitman's Poetry, Wynn Thomas argues that the poems of the 1850s struggle to preserve the face-to-face democracy of artisanal culture against the insurgence of large-scale industrialism and what Alan Trachtenberg calls "the incorporation of America." 14 According to Thomas, Whitman's vision was out of touch with the times even in his own day. The "old artisanal dream of a free, egalitarian commonwealth," which Whitman celebrated in the "aggressive new form" invented by the likes of Thomas Paine and Frances Wright, "was already antiquated by the 1820 s and totally out of step with the giant strides of capitalist development" (Thomas 29). The 1855 Leaves, in Thomas's view, was "the direct result of a plunging economic crisis that severely hit the bastard artisan class to which Whitman then loosely belonged" (Thomas 33). Finding himself, like many Americans, unable to find work as a house carpenter, a job he had undertaken with his father in the early 1850 s after stints at school teaching and newspaper writing, Whitman began to write exuberantly hopeful poems whose energy partly conceals social and political fears just beneath the surface, which Thomas sees as a source of aesthetically powerful tension. Granting the aesthetic appeal of the poems, Bryan Garman has recently asserted that Whitman's artisanal republicanism was not only belated but in fact reactionary and that the attractiveness of Whitman's stance to later social thinkers, poets, and songsters-from Horace Traubel and Eugene Debs down to Woody Guthrie, Bob Dylan, and Bruce Springsteen-led to the development of a working-class hero image that preserves sexist and racist elements at the core of American liberal thinking. According to Garman, the democratic character of the village artisans and farmers that Whitman admired tended to exclude people of other races and ethnic origins from the tightly knit workingmen's camaraderie and to closely circumscribe the position of women as well. Along these lines, Whitman's grandiose denial of the distance between himself and others (on the street, in the print medium, and across historical and cultural distances) may seem uncomfortably close to the rhetorical strategies that critics these days associate with imperial, colonial, racist, and masculinist discourses. ${ }^{15}$ 
Critics like Thomas and Garman focus primarily on the social and political aspects of Whitman's artisanal republicanism, but we might also add a geographical dimension. The old artisans were the product of village or small town life. Their ways of life as well as their mode of production could not withstand urbanization and incorporation. Whitman's poems represent an effort to transplant the old ways or translate village life for use in the city. ${ }^{16}$ From this perspective, Leaves of Grass gives us a protagonist familiar in the art of urbanization, from Hawthorne's "My Kinsman, Major Molineaux" down to contemporary films like "Crocodile Dundee." The Whitmanian "myself" thus appears not as the arrogant misogynist, stealthy racist, or imperial self, but as the overly familiar bumpkin, treating city strangers like old family friends, confronting urban aliens with the kind of insistent recognition formed in towns where everyone knows you, as Whitman would say, by your "nighest name."

Significantly, whenever Whitman reaches for a strong example of the kind of public intimacy he longs for, his mind drifts back to the rural setting he knew as a village boy on Long Island. The model characters he presents to the reader come from his parents' generation, such as the old farmer in "I Sing the Body Electric," a poem which dates from 1855:

I knew a man . . . . he was a common farmer . . . he was the father of five sons . . and in them were the fathers of sons ... and in them were the fathers of sons.

This man was of wonderful vigor and calmness and beauty of person;

The shape of his head, the richness and breadth of his manners, the pale yellow and white of his hair and beard, the immeasurable meaning of his black eyes,

These I used to go and visit him to see .... He was wise also,

He was six feet tall .... he was over eighty years old . . . his sons were massive clean bearded tanfaced and handsome,

They and his daughters loved him . . . all who saw him loved him . . . they did not love him by allowance . . . they loved him with personal love;

He drank water only .... the blood showed like scarlet through the clear brown skin of his face;

He was a frequent gunner and fisher ... he sailed his boat himself . . . he had a fine one presented to him by a shipjoiner ... . he had fowling-pieces, presented to him by men that loved him;

When he went with his five sons and many grandsons to hunt or fish you would pick him out as the most beautiful and vigorous of the gang,

You would wish long and long to be with him . . . . you would wish to sit by him in the boat that you and he might touch each other. (119-120, punctuation thus in original)

The portrait gives us the image of the village patriarch whose age and fertility, as well as his skill as a farmer, hunter, and sailor, account partly for his status, which is acknowledged by gifts given by local admirers and craftsmen - the fowling piece and the boat, and finally the poem 
itself, given by the artisan poet, whose admiration for the old man is rooted in the physical magnetism of his presence. The memory of how the patriarch commands the love of others inspires the general principle that follows in the next lines of the poem, which express the universalizing trend of Whitman's vision for the new urban life. "I have perceived that to be with those I like is enough," he says, "To be surrounded by beautiful curious breathing laughing flesh is enough, / To pass among them . . to touch any one .... to rest my arm ever so lightly round his or her neck for a moment" (120). But we should note how in these lines the kinds of specific details that grace the passage about the beautiful old man are now absent, leaving a generalized picture of an abstract community (that involves "any one" and "his or her neck"), a model for current life waiting to be filled in (or not).

When Whitman tries to imagine himself as the center of admiration in an urbanized culture of craftsmen, the result is similarly vague. In another 1855 poem, the fantastical dream vision titled "The Sleepers" in later editions, appear these lines, for example:

Well do they do their jobs, those journeymen divine,

Only from me can they hide nothing and would not if they could;

I reckon I am their boss, and they make me a pet besides,

And surround me, and lead me and run ahead when I walk,

And lift their cunning covers and signify me with stretched arms, and resume the

way;

Onward we move, a gay gang of blackguards with mirthshouting music and

wildflapping pennants of joy. (108)

The use of the term "journeymen" is significant in hearkening back to a group of skilled artisans who remained free to work from job to job and were thus not fully subject to capitalist control - the very group that was disappearing into the new system that Thomas describes. The movement in the streets and the unruly camaraderie may even suggest the sort of situation that erupted into worker's riots frequently during the economic troubles of mid-century New York, with its the growing pains associated both with urbanization and with market fluctuations arising from foreign trade, the emerging globalization on which the great port of New York depended for its ascendancy. But again the detail is missing. These "journeymen divine" have no faces and are ironically reduced to their function, serving the boss who is also their pet. So schematic is the representation of this "gay gang of blackguards" that we are tempted to see them as symbolic, perhaps a trope for some characteristics of the speaker himself, or again as a hopeful model yet to be filled in or fleshed out, Whitman's artisanal ideal applied vaguely to the realities of urban life. The use of the adjective "divine" recalls Thomas's criticism of Whitman's "prattlings about the soul." The recourse to metaphysical language is an early instance of what Thomas sees as a typical 
strategy Whitman employed in later poems when his self-doubt reached a zenith: "the trick . . . of turning up the volume of his rhetoric in order to drown out the noise of his doubts" (Thomas, 12-13, 266).

But "The Sleepers" also gives us a more vivid picture of human sympathy. Not surprisingly, the vision appears in another vignette from village life taken from the previous generation. The story seems intended to provide a model for affection arising from chance encounters, a situation which will become for Whitman (as it did for Baudelaire) a poignant phenomenon of city life:

Now I tell what my mother told me today as we sat at dinner together,

Of when she was a nearly grown girl living home with her parents on the old homestead.

A red squaw came one breakfasttime to the old homestead,

On her back she carried a bundle of rushes for rushbottoming chairs;

Her hair straight shiny coarse black and profuse halfenveloped her face,

Her step was free and elastic . . . . her voice sounded exquisitely as she spoke.

My mother looked in delight and amazement at the stranger,

She looked at the tallborne face and full and pliant limbs,

The more she looked upon her the more she loved her,

Never before had she seen such wonderful beauty and purity;

She made her sit on a bench by the jamb of the fireplace . . . . she cooked food for her,

She had no work to give her but she gave her remembrance and fondness.

The red squaw staid all the forenoon, and toward the middle of the afternoon she went away;

O my mother was loth to have her go away,

All the week she thought of her . . . . she watched for her many a month,

She remembered her many a winter and many a summer,

But the red squaw never came nor was heard of there again. (112-113, punctuation thus in original)

The passage holds out the possibility of love among strangers, momentary but deep. But the setting of the "old homestead" seems to matter in a special way. The possibility of chance intimacy increases with the old habit of entertaining strangers who come calling unexpectedly. The theme was still viable in the rural setting of country blues music in the early twentieth century, as we see, for example, in Mississippi John Hurt's old song "Make Me a Pallet on Your Floor," with the lines, "Never turn a stranger from your door, / Might be your best friend come calling and you would never know." The idea of admitting unknown people at the door can only seem dangerous to people weaned on urban experience.

And yet again and again, Whitman celebrates the possibility of not only hospitality but even love among strangers in city life. The poem “Once I Pass'd through a Populous City" offers a good example: 
Once I pass'd through a populous city imprinting my brain for future use with its shows, architecture, customs, traditions,

Yet now of all that city I remember only a woman I casually met there who detain'd me for love of me,

Day by day and night by night we were together - all else has been long forgotten by me,

I remember I say only that woman who passionately clung to me,

Again we wander, we love, we separate again,

Again she holds me by the hand, I must not go,

I see her close beside me with silent lips sad and tremulous. (266)

The sad and tremulous lips offer the single detail of an otherwise schematic portrait, which, compared to the loving image conjured by the mother's memory of the Indian woman, seems sketchy to the point of being unconvincing. Yet more remarkable is the fact that the manuscript for the poem reveals that it was originally about a man, not a woman. By the time he published the poem in the 1860 Leaves of Grass, Whitman had changed the gender of the lover from the populous city. ${ }^{17}$ This now famous revision may well have been an effort to conceal the homosexual emotion of the poem, but we need also to recognize that the quality of interchangeability is made possible by the abstracting imagination of the urbanizing experience. The faceless one who "detains" the poet is hardly a person at all but rather a fantasy figure, an image perhaps of unfulfilled longing reduced to the virtual synecdoche of lips sad and tremulous, the gender a matter of indifference.

Still it would be a mistake to ignore the homosexual motive altogether. Whitman's homoeroticism has come to be most frequently associated with the group of poems he called "Calamus," which like "Once I Pass'd Through a Populous City" was first published in the 1860 Leaves of Grass. ${ }^{18}$ Here, against a background of advancing ambivalence about urban life, we see Whitman beginning to struggle with his earlier faith in the sympathetic imagination as a foundation for the love of comrades.

\section{"Calamus": Citified Skepticism and Urbane Doubt}

Doubt, for Whitman, cannot be a mode of being (as it is for later poets like T.S. Eliot). Less tolerable than the idea of death, doubt is a sharp pain, an illness that takes him by surprise and must be cured or dismissed. It is also one of the least characteristic attitudes of the poet of Leaves of Grass. His struggle against doubt appears to have intensified around the end of the 1850 s, a period that includes the early manuscripts toward the poems that became the "Calamus" section of the 1860 Leaves. Dating from 1859, the "Live Oak, with Moss" sequence of twelve numbered lyrics loosely narrates the course of a failed love affair with a man. Though this manuscript eventually forms the backbone of the forty-five poems that constitute the 1860 version of "Calamus," in this early version the poems tell a darker story than Whitman 
ultimately permits to be made public. ${ }^{19}$ These lyrics, unlike the finished "Calamus" series, take the "live oak with moss" as their emblem, rather than the phallic calamus grass. This difference is significant in that the calamus grass grows in groups, while Whitman originally picks out the live oak for attention because of its lonely splendor ("solitary in a wide flat space"). The tree reminds him of manly love (the sprig of leaves and moss that he brings away "remains to me a curious token"), but standing so isolated, "without a friend, a lover, near," the live oak suggests the fearful chance of solitude that always lurks behind love. In the "Live Oak" manuscript sequence, Whitman comes face to face with isolation and doubt: self-doubt, doubt about his knowledge of others, and doubt about what others know of him. This doubt in all cases serves to distance him from human contact and a sense of belonging to a community.

The doubting impulse breaks into full articulation in lyric VII, "Hours continuing long." Though Whitman retained this poem in the 1860 "Calamus," he cut it from the 1867 Leaves and all subsequent editions.

Hours continuing long, sore and heavy-hearted,

Hours of the dusk, when I withdraw to a lonesome and unfrequented spot, seating myself, leaning my face in my hands,

Hours sleepless, deep in the night, when I go forth, speeding swiftly the country roads, or through the city streets, or pacing miles and miles, stifling plaintive cries,

Hours discouraged, distracted,-For he, the one I cannot content myself withoutsoon I saw him content himself without me,

Hours when I am forgotten- $-(\mathrm{O}$ weeks and months are passing, but I believe I am never to forget!)

Sullen and suffering hours-(I am ashamed-but it is useless- I am what I am;)

Hours of my torment-I wonder if other men ever have the like, out of the like feelings?

Is there even one other like me-distracted-his friend, his lover, lost to him?

Is he too as I am now? Does he still rise in the morning, dejected, thinking who is lost to him? And at night, awaking, think who is lost?

Does he too harbor his friendship silent and endless? Harbor his anguish and passion?

Does some stray reminder, or the casual mention of a name, bring the fit back upon him, taciturn and deprest?

Does he see himself reflected in me? In these hours does he see the face of his hours reflected?

The severest pang of the speaker's melancholy is expressed in the center of the poem-"I wonder if other men ever have the like, out of the like feelings?"- and the intensity of the experience renders the poet for the moment mute to describe it. It is the experience of radical epistemological solitude, in which the sufferer, doubting that his thoughts and feelings have a counterpart in others' minds, finds himself cut off even from imaginary human contact. In ordinary social interaction, skepticism is precluded by the assumption that others think and feel in ways basically 
similar to our own, and that their behavior can be used as evidence for those thoughts and feelings. Yet when that assumption fails in one case, its failure may cast doubt on the whole enterprise of understanding others. Here, the failure of understanding between the speaker and the lover who has rejected him ("he, the one I cannot content myself without-soon I saw him content himself without me") calls into question the fundamental analogy structuring his relations with the world: "Is there even one other like me?" This is the analogy between self and others that makes "Crossing Brooklyn Ferry" possible: "Just as you feel when you look on the river and sky, so I felt. . . ."

The second half of "Hours continuing long" attempts to patch this analogy back together in the form of questions. These questions- "Does he still rise . . .," "Does he too harbor his friendship . . .," "Does some stray reminder . . . ?"-posit some imaginary "like" man who experiences suffering in the same way the speaker does. Though framed as questions, these detailed descriptions make such a man plausible, bring him halfway into being. Whitman's closing line indicates the direction of his anti-skeptical strategy: "Does he see himself reflected in me?" This question suddenly changes what had seemed to be a private utterance (in a "lonesome and unfrequented spot") to public speech. No longer a private lament, the poem becomes a published self-revelation and invitation to others to sympathize. While failing to establish the existence of a sympathetic reader, the closing question suggests a communicative purpose to the whole utterance: to give comfort to the "like" man who reads the poem in his own solitude. By turning the tables (from his own isolation, to his reader's), Whitman takes a step towards reconstructing the analogy of self to others that doubt has undermined.

Whitman's failure to convince himself of the success of this reconstruction, however, is confirmed by his decision to remove the poem from Leaves of Grass after 1860. Furthermore, his 1860 "blue book" (the copy in which he marked potential revisions) indicates precisely the lines that most offended his sense of the consistency of his poetic self-presentation. The lines crossed out include "O weeks and months are passing, but I believe I am never to forget!," "I am ashamed-but it is useless-I am what I am," and "I wonder if other men ever have the like, out of the like feelings." 20 These lines at the heart of the lyric could not be cut without gutting the thought driving it; hence his ultimate decision to edit the poem entirely out of Leaves of Grass. Its existence in the body of "excluded" poems, nevertheless, illuminates the entire progress of "Calamus," a series strung between doubt and desire for confirmation. Though no other part of the sequence confesses such despair, Whitman's attempt to resist the pull of doubt is everywhere. Poems from the full 1860 "Calamus" group that articulate the problem of misleading appearances include "Earth my likeness" (Calamus 36), 
"O you whom I often come" (Calamus 43), "Are you the new person drawn toward me" (Calamus 12), "You bards of ages hence" (Calamus 10), "Whoever you are holding me now in hand" (Calamus 3), "Of the terrible doubt of appearances" (Calamus 7), "To a Stranger" (Calamus 22), and others. Like "Hours continuing long," a number of these poems attempt to shift the burden of doubt from poet to reader/lover, as a way of dissipating it, but the central tension between doubt and desire for confirmation remains intact.

"Hours continuing long" explicitly stages the speaker's doubt and despair as a withdrawal from the places of human habitation and activity: "Hours of the dusk, when I withdraw to a lonesome and unfrequented spot . . . deep in the night, when I go forth, speeding swiftly the country roads, or through the city streets ...." In a group of poems that begins with the words "In paths untrodden," this staging is clearly emblematic of an important theme of leaving the city and its press of people. Though he doesn't eschew the city entirely, he continues to inhabit it only at night, when he can avoid confrontation with its crowds of busy strangers. This withdrawal complements his sense of epistemological and sympathetic isolation from all other humans. Human contact, both intimate and casual, is replaced in the poem by the anonymous, mediated, remote contact of reader and poet. ${ }^{21}$ This process of withdrawal from urban density will be recapitulated in several ways in the 1860 "Calamus" group, though in those subsequent poems, Whitman is primarily concerned to validate private intimacy over casual contact with the crowd. "Hours continuing long" suggests that the impulse towards seclusion derives originally from a sense of doubt and betrayal, rather than satisfaction and mutuality in love.

The topos of withdrawal from the city and the structuring epistemological tension of doubt and confirmation in "Calamus" are the key coordinates for placing Whitman in the context of urbanization and pragmatism. Both themes (exit from the city and the struggle against doubt) are present throughout the sequence, but in widely varying combinations, as though Whitman himself were experimenting to find out their relation. It is at least clear that by 1860 Whitman no longer finds the crowded public spaces of the city an appropriate metaphor for human connectedness. This shift may have many possible causes. As Wynn Thomas argues, the development of Manhattan over the period of the 1850 's may have been superficially exhilarating, but really showed the demise of the artisan republicanism Whitman had championed. A large influx of unskilled Irish immigrants during this period also swelled the ranks of the class of semi- or unskilled workers who inhabited lower Manhattan. At the same time, the city-dwelling poor were continuously pressed into less and less residential space, as houses were torn down to make way for businesses. ${ }^{22}$ As a consequence of this overcrowding, public spaces in lower Manhattan testified less to a healthy democracy than to 
an exploitative profit-driven commerce-machine. Terrible sanitation conditions for the less-well-off (paying to hook up to a rudimentary sewer system was voluntary for landlords, who mostly didn't) aggravated the situation, producing an awful stench and extremely unhealthy environment. ${ }^{23}$ (Whitman's description in Calamus 17 of "Chicago, Boston, Philadelphia, the Mannahatta" as "fuller of the dead than of the living" is more literal than it might at first seem.) Many New Yorkers who could afford to moved to the suburbs (including Whitman's Brooklyn) or escaped there during the summer months. In part, Whitman's response to urbanization in the late 1850's can be understood as an adjustment to a changing city: crowds with whom Whitman had less in common socially, an economy from which he felt alienated, and sights and smells that even the greatest aesthetic effort could not make appealing.

Whether his doubt in the power of sympathetic understanding derived first in his life from romantic disappointment or from disillusionment with urban life is less important than that the urban crowd simply ceases, in the new poems of the 1860 Leaves of Grass, to serve as the staging-ground for his acts of connection and the source of confirmation. However it enters his poetry, the blight of skepticism cannot be alleviated by pointing out the similarity of perception shared by unrelated strangers. Instead, Whitman dramatizes a retreat in "Calamus" to "paths untrodden," remote or rural spots where intimate interaction can go ahead undisturbed. Crowds, which in the 1855 "Song of Myself" and 1856 "Crossing Brooklyn Ferry" testify to the common experience of Americans and provide fertile meeting-places for lovers, now only interfere with the progress of love. Preferred locations are outdoors and secluded, "escaped from the life that exhibits itself." Sometimes these locations encourage the solitary contemplation of his feelings ("In paths untrodden," "You bards of ages hence!"), and sometimes permit private intercourse with another ("Whoever you are holding me now in hand," "When I heard at the close of the day") or with a group of friends ("Singing in spring"). Urban scenes, in contrast, are carefully qualified by the speaker as not the object of his praise, but rather the accidental settings of encounters between comrades: "Not the pageants of you . . . Not the interminable rows of your houses ... Nor the processions in the streets . . . Not those-but, as I pass, O Manhattan! your frequent and swift flash of eyes offering me love, / Offering me the response of my own" ("City of my walks and joys," later "City of Orgies"; see also "What think you I take my pen in hand to record").

Though "Calamus" includes reports of anonymous romantic encounters in urban public spaces (for example, "To a Stranger"), these are the exception rather than (as in the 1855 Leaves) the rule. True understanding, as opposed to an erotic flashing of eyes, appears to take place only in seclusion. Thus in "Whoever you are holding me now in 
hand," the speaker warns that the "candidate for my affections" will only be able to encounter him "in some wood . . . . . in the open air, / (For in any roofed room of a house I emerge not . . .)." Seclusion in rural spots is one precondition of meeting, in body and mind.

And yet such seclusion is not necessarily sufficient to guarantee understanding. Doubt remains, cautions the speaker: "But these leaves conning, you con at peril, / For these leaves, and me, you will not understand, / They will elude you at first, and still more afterward-I will certainly elude you...." Naturally, part of the issue is the socially unsanctioned nature of the love that the speaker here advocates ("I am not what you supposed, but far different"; "For all is useless without that which you may guess at many times and not hit - that which I hinted at"). Neither by reading his poems nor by knowing him, the speaker cautions, can one really understand or "catch" him. There is an excess of mystery that answers cannot satisfy. This free-floating, excessive quality in part derives from the nature of skepticism itself: the problem of appearances, in particular the problem of other minds, has no straightforward "solution," and the more we dwell on it, the more that doubt infuses all our thinking.

Whitman addresses this aspect of doubt more explicitly in "Of the terrible question of appearances" ("question" changed to "doubt" in 1867 and subsequent editions). This poem, belonging to the 1860 " $\mathrm{Ca}$ lamus" group, proposes the problem in quite philosophical terms:

Of the terrible question of appearances,

Of the doubts, the uncertainties after all,

That may-be reliance and hope are but speculations after all,

That may-be identity beyond the grave is a beautiful fable only,

May-be the things I perceive-the animals, plants, men, hills, shining and flowing waters,

The skies of day and night - colors, densities, forms-May-be these are, (as doubtless they are,) only apparitions, and the real something has yet to be known,

(How often they dart out of themselves, as if to confound me and mock me!

How often I think neither I know, nor any man knows, aught of them;)

May-be they only seem to me what they are, (as doubtless they indeed but seem,) as from my present point of view-And might prove, (as of course they would,) naught of what they appear, or naught any how, from entirely changed points of view;

To me, these, and the like of these, are curiously answered by my lovers, my dear friends;

When he whom I love travels with me, or sits a long while holding me by the hand,

When the subtle air, the impalpable, the sense that words and reason hold not, surround us and pervade us,

Then I am charged with untold and untellable wisdom-I am silent-I require nothing further,

I cannot answer the question of appearances, or that of identity beyond the grave,

But I walk or sit indifferent-I am satisfied,

He ahold of my hand has completely satisfied me. (Blue Book 352-353) 
The first nine strophes of the poem beautifully express the spiraling quandary of skepticism, with its qualifications, interruptions, and selfcancellations - a world of doubt out of which no line of reasoning seems able to lead. Into this vortex fall not only other minds ("men"), but all visible things, as well as ideas and the hopes we pin on those ideas. No evidence can resist the onslaught of doubt (the question "How do you know" always remains to be asked again). The "curious" answer to this problem thus is not (cannot be) philosophical, but social: the speaker turns away from his thoughts and towards his lover. The confirmation of the lover's presence halts the collapse of knowledge and fills in the gap with a mute "wisdom" that does not need to answer skeptical questions directly. He is "satisfied."

In contrast to "Whoever you are," this poem is almost guileless in its presentation of the problem of doubt, openly acknowledging that skepticism cannot be satisfied by its own means. How does the speaker know that his lover's affection isn't merely an appearance? He certainly doesn't know, as he admits, but he chooses to go on with human intercourse regardless. The "turn" in the center of this poem sets a pattern in "Calamus" for the problem of doubt, which Whitman consistently raises and then drops. The response to skepticism is social confirmation-social interaction in a community of like-minded agents and inquirers-but there is no pretense that confirmation actually resolves doubt about other minds.

What, then, is the nature of this "confirmation" that the "Calamus" speaker seeks, and sometimes finds? It is, we have seen, primarily not urban; it is conceived as an alternative to the scenes of mass democracy present in "Crossing Brooklyn Ferry." We should not thereby conclude that it is simply a more exclusive, suburban, social phenomenon. In "Whoever you are now holding me in hand," the retreat to a spot "on a high hill-watching lest any person, for miles around, approach unawares" offers the opportunity for sexual intimacy and/or uninterrupted reading. This is Whitman's standard trope: likening physical touching to the consumption of poetry, to the point where it is not clear what is literal and what figurative. Similarly, it is not clear whether the confirmation the speaker seeks is from lovers or from readers. If from readers, then an actual retreat from the city may not be necessary; the book itself provides the secluded space of communion between poet and reader. This possibility widens and changes the concept of confirmation considerably. "Hours continuing long" makes explicit the problem with relying on confirmation from a single individual: betrayal by a lover may fatally undermine the whole principle of likeness and response. The reader-poet relationship, on the other hand, is less subject to betrayal precisely because it is less personal, more abstract. Confirmation from readers is also broader, stretching across geography and into the future; 
it is largely imagined and potential. Ultimately, as well, it recapitulates the sense of public space lost by Whitman's staged retreat from the city. ${ }^{24}$

Though the early "Live Oak, with Moss" sequence tends to privilege intimate love almost to the exclusion of poetry, the finished "Calamus" reverses that tendency, proclaiming Whitman the bard of manly love. "I am indifferent to my songs" (from "Long I thought that knowledge alone would suffice") gives way to "For you these from me, $\mathrm{O}$ Democracy, to serve you ma femme! / For you, for you I am trilling these songs." This transition indicates Whitman's resumption of the project of poetry as public institution par excellence, temporarily abandoned during a period of personal and historical crisis. It turns out that this institution, though virtual, is far more stable than any single instance of the love of comrades. Though the presence of a comrade provides a temporary sense of security to the skeptical poet in "Of the terrible doubt of appearances," Whitman ultimately comes to rely on the confirmation provided by the hypothetical or imagined community of readers.

Like the pragmatists, Whitman responds to the troubling question "what is behind it all?" not by answering directly but by affirming the vehicle, the institution, of response itself. "Poetry," like the pragmatists" "community," has no specific content but rather facilitates the human impulse to seek and offer confirmation. Skepticism isolates the individual and widens the field of his questions; poetry excludes questions that cannot be answered and changes the subject to one in which confirmation is possible. Whitman withdraws from his earlier intense engagement with the city as a way of withdrawing from the vortex of doubts that begin to plague him there. In the place of that bustling space of physical and social contact (that, nevertheless, does not guarantee mutual understanding), he substitutes the virtual space of poetry, a set of intimate yet anonymous relations between the poet and his individual readers.

Whitman's naming of "poetry" as the solution to philosophical and political problems belongs to the Romantic and modernist tendency to apotheosize poetry in the absence of any other convincing transcendental principle, but his strategy also shares a family resemblance with pragmatism, as we have argued. ${ }^{25}$ Widely differing in their attitudes both to truth and to the proper object of pragmatic methods, Peirce, Royce, James, and Dewey all concurred on the centrality of community and communal exchange. For them, "community" was neither a place nor any particular social configuration, but rather the process of comparing notes that takes place among persons with a collective aim (whether that aim is scientific inquiry, the maintenance of religious faith, political 
cooperation, education, or another purpose). They shared with each other and with Whitman an optimistic faith in the process of exchange and communication to produce true answers or beneficial solutions.

Although this strategy sounds well and good, in practice it has the tendency to become reified and removed from actual, communicating groups of persons. Whitman's later work gives play to an increasing level of abstraction and generality, often neglecting the kind of sensory detail and immediacy that makes the early work so rich and compelling. This development is not necessarily the fault of his conception of poetry as a substitute for the actual urban ground of interpersonal interaction, but at least the two changes go hand in hand. Similarly, much of the socially innovative force of pragmatism was absorbed into the movement to professionalize city government, a political reform that points away from participatory democracy, and away from a conception of the city as an organic community. ${ }^{26}$

Peirce's theory of the community of inquiry had technocratic implications from the beginning; the community is defined as a group of scientific experts. ${ }^{27}$ During the early decades of the twentieth century, the popular progressive effort to professionalize and introduce "expertism" to many areas of endeavor made use of the technocratic element in pragmatism as theoretical justification, despite the politically and socially progressive tendency of Dewey's work during the same period. Herbert Croly and Walter Lippmann, both of whom studied philosophy at Harvard with members of the pragmatist group, went on to advocate for government by experts, whose superior knowledge and disinterestedness were presumed to generate a more just and efficient management of public affairs. ${ }^{28}$ (One of Croly's disciples, the notorious Frederick Taylor, promoted a scheme for the "scientific management" of labor along the same technocratic lines, a science which produced the modern-day practice of personnel management.) One of the practical instantiations of this pragmatist-influenced political theory in the 1910 s and 1920s was the movement to convert city government from the traditional model of an elected mayor and council to a commission or city manager model, as a way of protecting municipal government from corruption and increasing its administrative efficiency. ${ }^{29}$ The professionally trained manager, though answerable to the elected five-member commission that appointed him, is invested with full power to govern and develop the city as he sees fit, on the assumption that the electorate is not really competent to select a suitable administrator nor to judge municipal policy except very remotely.

The city-manager plan indicates a kind of disillusion with the capacity of the urban community to work together and to know its best interests-much in the same way, we suggest, that Whitman's earlier withdrawal from the city indicates the poet's skepticism about knowing other minds. Pragmatism can be understood as a kind of response to 
urbanization, a response affirming the processes and institutions of community. Yet process itself is not guaranteed to solve problems, philosophical or political. Nor is "community" necessarily a socially progressive conception: the outcome of process depends, as it ever did, on the persons who put it to work, and their specific ends.

University of Missouri

Texas A\&M University

\section{NOTES}

1 Justin Kaplan, Walt Whitman: A Life (New York: Simon and Schuster, 1980), 107.

2 William James, Talks to Teachers on Psychology: and to Students on Some of Life's Ideals (1892), ed. Paul Woodring (New York: Norton, 1958), hereafter abbreviated as James; Richard Rorty, Achieving Our Country (Cambridge: Harvard University Press, 1998). See also Raphael C. Allison, "Walt Whitman, William James, and Pragmatist Aesthetics," Walt Whitman Quarterly Review 20 (2002), 19-29; and Stephen Mack, The Pragmatic Whitman (Iowa City: University of Iowa Press, 2002).

3 Philosophical Writings, trans. John Cottingham (New York: Cambridge University Press, 1984), 2:21.

4 Baudelaire, The Flowers of Evil (bilingual edition), trans. James McGowan (New York: Oxford University Press, 1993), 188-189.

5 "Whitman's Lesson of the City," Breaking Bounds: Whitman and American Cultural Studies, ed. Betsy Erkkila and Jay Grossman (New York: Oxford University Press, 1996), 166.

6 Peirce, "How to Make Our Ideas Clear," Collected Papers of Charles Sanders Peirce, vol. 5, Pragmatism and Pragmaticism, ed. Charles Hartshorne (Cambridge: Belknap Press, 1934), 407, p. 268. Originally published in Popular Science Monthly, 1878.

7 Peirce, Collected Papers, vol. 5, 311, p. 186. Originally published in fournal of Speculative Philosophy, 1868.

8 Royce, The Problem of Christianity, ed. John E. Smith (Chicago: University of Chicago Press, 1968).

9 See Royce, The Religious Aspect of Philosophy (Boston: Houghton Mifflin, 1885), $157 \mathrm{ff}$.

10 Unless otherwise noted, all quotations of Whitman's poems are from Complete Poetry and Collected Prose (New York: Library of America, 1982) and are cited by page number.

11 Quoted in Jerome Loving, Walt Whitman: The Song of Himself (Berkeley: University of California Press, 1999), 6.

12 M. Wynn Thomas, The Lunar Light of Whitman's Poetry (Cambridge, Mass: Harvard University Press, 1987), 108.

13 Ralph Waldo Emerson, Essays and Lectures (New York: Library of America, 1983), 259. 
14 Alan Trachtenberg, The Incorporation of America: Culture and Society in the Gilded Age (New York: Hill and Wang, 1982).

15 Bryan K. Garman, A Race of Singers: Whitman's Working-Class Hero from Guthrie to Springsteen (Chapel Hill: University of North Carolina Press, 2000). See also Quentin Anderson, The Imperial Self: An Essay in American Literary and Cultural History (New York: Knopf, 1971); Betsy Erkkila, Whitman the Political Poet (New York: Oxford University Press, 1989); Walter Grünzweig, "Noble Ethics and Loving Aggressiveness: The Imperialist Walt Whitman," An American Empire: Expansionist Cultures and Policies 1881-1917, ed. Serge Ricard (Aix-en Provence: Université de Provence, 1990), 151-165; Vivian Pollak, The Erotic Whitman (Berkeley: University of California Press, 2000); and David Simpson, "Destiny Made Manifest: The Styles of Whitman's Poetry," Nation and Narration, ed. Homi Bhabba (New York: Routledge, 1990), 177-96.

16 For an ecocritical reading of Whitman's Romantic urbanism, see Lawrence Buell, Writing for an Endangered World: Literature, Culture, and Environment in the U.S. and Beyond (Cambridge: Harvard University Press, 2001).

17 See Loving, 249-250.

18 See M. Jimmie Killingsworth, Whitman's Poetry of the Body (Chapel Hill: University of North Carolina Press, 1989) for a reading of the homoeroticism of Leaves of Grass within the context of nineteenth-century sexual attitudes on the American scene. For different but related perspectives, see Robert K. Martin, The Homosexual Tradition in American Poetry (Austin: University of Texas Press, 1979); Byrne R.S. Fone, Masculine Landscapes: Walt Whitman and the Homoerotic Text (Carbondale: Southern Illinois University Press, 1992); Michael Moon, Disseminating Whitman: Revision and Corporeality in Leaves of Grass (Cambridge: Harvard University Press, 1991); and Pollak, The Erotic Whitman. For a brief review of relevant scholarship and a look at Whitman's role in the development of a rhetoric suggesting a distinctly gay sensibility, see Killingsworth, "Whitman and the Gay American Ethos," A Historical Guide to Walt Whitman, ed. David S. Reynolds (New York: Oxford University Press, 2000), 121151.

19 See Fredson Bowers, "Whitman's Manuscripts for the Original 'Calamus' Poems," Studies in Bibliography 6 (1953), 257-265; Alan Helms, "Whitman's 'Live Oak with Moss," The Continuing Presence of Walt Whitman, ed. Robert K. Martin (Iowa City: University of Iowa Press, 1992), 185-205; and Hershel Parker, "The Real 'Live Oak, with Moss': Straight Talk about Whitman's 'Gay Manifesto,'” Nineteenth-Century Literature 51 (1996), 145-160. Our quotations from the manuscript of "Live Oak, with Moss" come from The Walt Whitman Archive, ed. Ed Folsom and Kenneth M. Price, available online at http://www.whitmanarchive.org.

20 See Walt Whitman's Blue Book: The 1860-61 Leaves of Grass Containing His Manuscript Additions and Revisions, ed. Arthur Golden (New York: New York Public Library, 1968), 1:355. Hereafter abbreviated as Blue Book.

21 See Peter Coviello, "Intimate Nationality: Anonymity and Attachment in Whitman," American Literature 73 (2001), 85-119.

22 In the 4th and 6th wards on the Lower East Side, where the greatest concentration of Irish immigrants lived, some 45,000 people crowded one-quarter of a square mile in 1850 . By 1866 , "a sanitary inspector reported that in the 4 th ward . . . developments had reduced residential space by one-third since the early 1850 's, without reducing the total number of inhabitants. By that time, the area had developed into a 
23 During the 1850's, public health became so poor that deaths exceeded births, and the city size actually would have shrunk if not for new arrivals from inland and foreign nations. Common diseases included smallpox, yellow fever, cholera, cholera infantum, typhus, typhoid fever, measles, scarlet fever, dysentery, and tuberculosis. Though sanitation had never been good, a spike in residential crowding caused mortality rates to soar from these diseases. See Spann, 135-136.

24 Many critics have noticed the centrality of the trope of reading in "Calamus." See especially Russell Hunt, "Whitman's Poetics and the Unity of 'Calamus," American Literature 46 (1975), 482-494.

25 Though not in the direct line of argument for this paper, it is worth noting that pragmatism, too, originally arose out of the same unsettling search for a stable transcendental principle that motivates Romantic and post-romantic poetry. As Bruce Kuklick argues in The Rise of American Philosophy (New Haven: Yale University Press, 1977), Peirce's pragmatic theory cleverly reconciles Christian and scientific approaches in their common teleological orientation (leaving unspecified what finally guarantees the successful outcome of inquiry). An important precursor to Peirce's work, Francis Abbott's Scientific Theism (1885), also identifies this common ground. Though Peirce is not interested in religious accounts of the world, and indeed mocks them, his own theory leaves room for a transcendental principle. Rejecting the dominant Hegelian philosophy of the later nineteenth century, the pragmatists resituated the criterion of truth in the secular human community, rather than in Bradley's crypto-Christian principle of the "absolute." For the pragmatists as for Whitman, it was important to find assurance of the reality of the external world and others' minds, as well as criteria for a usable concept of truth, somewhere outside the individual subjective mind, but still relatively close to earth, as it were, in the human collectivity.

26 Kuklick remarks on the relationship between pragmatism and progressive reform (The Rise of American Philosophy, 311). Also see Thomas Haskell's interesting comparison of Peirce and Durkheim on professionalization in "Professionalism vs. Capitalism: R.H. Tawney, Emile Durkheim, and C.S. Peirce on the Disinterestedness of Professional Communities," The Authority of Experts, ed. T. Haskell (Bloomington: Indiana University Press, 1984), 180-225. On the development of professionalization as a feature of the Progressive movement, see Richard Hofstadter, The Age of Reform: From Bryan to F.D.R. (New York: Knopf, 1955), 148-168.

27 Royce's concept of "interpretation," as developed in Problems of Christianity, also relies heavily, though perhaps unintentionally, on the role of professional expertise, adducing examples of the interpretive relation between doctor and patient, lawyer and client, teacher and student. See also John Smith, Royce's Social Infinite: The Community of Interpretation (New York: Archon Books, 1969), 81.

28 See Croly, The Promise of American Life (1909); and Lippmann, Public Opinion (1922).

29 "The argument most frequently and vigorously urged on . . . behalf [of the citymanager plan] is that the distinction which it draws between the functions of representation and administration makes it possible to put the actual conduct of the city's business in the hands of a qualified expert" (Thomas Reed, Municipal Government in the United States [New York: The Century Company, 1926], 227). See also Herman James, "What is the city manager plan?" in the Bulletin of the University of Texas: Municipal Research Series, No. 6 (Feb. 20, 1915). 